\title{
Screening of New Insecticide Molecules against Cotton Mealybug, Phenacoccus solenopsis Tinsley (Homoptera: Pseudococcidae)
}

\author{
T. D. Nidheesh ${ }^{1 *}$, A. H. Jayappa ${ }^{1}$, A. N. Shylesha ${ }^{2}$, N. Nagaraju ${ }^{3}$ and H. M. Jayadeva ${ }^{4}$ \\ ${ }^{1}$ Department of Agricultural Entomology, College of Agriculture, University of \\ Agricultural Sciences, GKVK, Bengaluru-65, India \\ ${ }^{2}$ ICAR-National Bureau of Agricultural Insect Resources, Hebbal, Bengaluru-24, India \\ ${ }^{3}$ Department of Plant Pathology, College of Agriculture, University of \\ Agricultural Sciences, GKVK, Bengaluru-65, India \\ ${ }^{4}$ Department of Agronomy, College of Agriculture, University of Agricultural \\ Sciences, GKVK, Bengaluru-65, India \\ *Corresponding author
}

\section{A B S T R A C T}

Keywords

Phenacoccus solenopsis, thiamethoxam $25 \% \mathrm{WG}$, dinotefuran $20 \%$ SG, profenophos $50 \% \mathrm{EC}$

Article Info

Accepted:

20 February 2020

Available Online:

10 March 2020
A laboratory experiment was carried out to evaluate the bio-efficacy of selected new generation insecticides viz., Pymetrozine 50\% WG, Flonicamid 50\% WG, Dinotefuran 20\% SG, Thiamethoxam 25\% WG,Azadirachtin 1\% EC,Buprofezin 25\% SC and Profenophos 50\% EC against cotton mealybug, Phenacoccus solenopsis Tinsley by adopting normal bioassay techniques. A preliminary trial with three different dosages (below recommended, recommended and above recommended) were tried for each of the insecticidal treatments. The mortality of mealybugs was found to be more in the treatment with recommended dosage when compared to below recommended dose. Out of the seven insecticides screened against $P$. solenopsis under laboratory conditions, neonicotinoids such as thiamethoxam 25\% WG @ 0.40 g/l and dinotefuran 20\% SG @0.25 g/l were found to be most effective in reducing the mealybug population at recommended and above recommended doses. Thiamethoxam and dinotefuran recorded the highest mortality of mealybugs (97.78 and $90.56 \%$, respectively) after imposition of treatments across different durations of exposure.

\section{Introduction}

Cotton (Gossypium spp.), the "white gold" is an important cash crop and extensively cultivated fibre crop of the world. In India, recorded nearly 110 species of insects and mites which infest cotton.During the recent years, sucking pest menace has been the major constraint in cotton cultivation. Since 2008-09, mealybugs too have emerged as potential threat to cotton production at Central India. Widespread infestation of the 
mealybug, Phenacoccus solenopsis Tinsley (Hemiptera: Pseudococcidae) in India occurred over large areas of different cropping systems across the three cotton growing regions, attaining pest status during 2008. It has been a topic of research for insect taxonomists and applied entomologists in India due to its invasiveness, rapid spread, morphological and biological variations and the need for establishing an effective control strategy. They found infesting crops of different categories viz., food, fibre, fruit, ornamental, plantation and vegetable crops besides weeds. Mealybugs infest a wide variety of host plants especially high value crops and no plant is free from attack of one or the other species of these insects.

Therefore, effective management of mealybugs is very critical not only for producing optimum yields, but also for maintaining quality of the produce. However, management of mealybug is a challenging task as they are protected by waxy filaments, have high reproductive rate and have the ability to hide in cracks and crevices in soil and corners of plant parts. The mealybug population could potentially reach a high level and cause significant damage to a large number of economically important crops unless suitable and timely management practices are implemented.

In recent years several newer insecticide molecules have been introduced specifically for managing sucking insects on vegetable and fruit crops. Though, these molecules have not been tried in cotton ecosystem, they have been used successfully in several other crops for managing sucking insects.

The widespread infestation of the mealybug throughout the cotton [Gossypium spp.] growing regions often requires expensive and numerous applications of insecticides to produce and protect the crop.
Selective insecticides that target pest species could play a role in conserving this wide diversity of natural enemies. Several insecticides that are widely used to suppress various pests can disrupt the effectiveness of these beneficial agents. It is less clear to what degree insecticides are disruptive with other non-target organisms.

Improved understanding of pest-natural enemy-insecticide interactions will assist in formulating more effective Integrated Pest Management strategies, the continuous and indiscriminate use of synthetic chemicals in plant protection resulted in toxicity to nontarget beneficial organisms. Therefore, farmers tend to use selective pesticides along with the bio control agents.

Most of the new insecticide molecules have been tried in various crop plants infested by different species of mealybugs other than Phenacoccus solenopsis. Among the novel insecticides buprofezin, pymetrozine, flonicamid, dinoteforan and azadiractin were reported for their insecticidal properties and proved effective in managing the pink mealybug, Maconellicoccus hirsutusGreen on different crops, are less toxic to natural enemies and quickly degrade in the environment (Muthukrishnan et al., 2005 and Ghelani et al., 2014). Therefore, the present investigation aims to determine the efficacy of select new insecticide molecules against solenopsis mealybug to find suitable alternatives to old chemical insecticides for sucking pest management in Bt cotton.

Many new generation insecticide molecules with novel modes of action have been registered in India for managing insect pests, particularly sucking pests. These new molecules are not only specific in their action against sucking insects, but also are either moderately or slightly toxic to mammals. Some of these molecules have been proved to 
be most effective on mealybugs. Under these circumstances, there is a need to understand the efficacy and safety of new insecticide molecules towards the mealybug and its natural enemies to develop effective and sustainable management strategies.

\section{Materials and Methods}

The mealybugs were first collected from the cultivated and uncultivated fields having profuse growth of alternative hosts viz., country mallow (Sida cordifolia L.), broom weed (Sida acuta), Indian mallow (Abutilon indicum), shoeblack plant (Hibiscus rosasinensis)and congress grass (Parthenium hysterophorus L.).The culture was maintained under glasshouse conditions so that there will be no loss of mealybug population due to natural enemies or no direct impact of the rain, the pest survived better under controlled conditions than in the open environment, where they are more prone to direct impact of rainfall as well as their natural enemies.

A preliminary experiment or feeler test had been carried out with three different dosages (below recommended, recommended and above recommended) of selected insecticides (Table 1) to confirm their efficacy and suitability against cotton mealybug, $P$. solenopsis under glass house conditions. To accomplish this study, potato sprouts were maintained in the laboratory as a substrate for the multiplication of $P$. solenopsis. The pretreatment count of the mealybug was kept at 20 numbers for all replications per treatment.

Bioefficacy of various insecticide molecules having novel modes of action were initially tested in the laboratory at different concentrations against cotton mealybugs. The purpose of the study was to determine the insecticide that will be effective on cotton mealybug and also to find out the effective concentrations for further field efficacy studies.
Potato slices with sprouts were washed and shade dried before usage. These potato slices with sprouts of uniform size were dipped in test insecticidal suspensions for $1 \mathrm{~min}$. with gentle agitation, and were placed on tissue paper to drain out excess test solutions for about 10 minutes and were placed in plastic containers. Fifteen third instar nymphs from laboratory reared homogeneous population of $P$. solenopsis were released onto each treated sprout and the plastic containers were covered with black cloth.

Each treatment was replicated thrice. Mealybug mortality was recorded at 24, 48, 72, 96and 120 hours after exposure to insecticides. Nymphs that fail to show movement after a gentle touch with a blunt lead pencil or camel hair brush was considered as dead. The cumulative per cent mortality of the nymphs was worked out for each treatment. The mortality data was transformed into arcsine values and then subjected to ANOVA.

Initially, a preliminary trial or experiment was conducted to elucidate the efficacy and compatibility or suitability of selected insecticides at three different doses (below recommended, recommended and above recommended). Based on the results of this preliminary experiment, dosages for bioassay were fixed.

\section{Results and Discussion}

\section{Efficacy of insecticides at recommended doses against $P$. solenopsis under laboratory conditions}

The effect of insecticides in different dosages against mealybugs on treated potato sprouts in the laboratory exhibited significant results (Table 2). Almost all the insecticides showed positive response on mortality of mealybug crawlers from the first day (24 Hours After 
Treatment) till fifth day (120 HAT) after treatment imposition. At 24 HAT, thiamethoxam 25 WG @ 0.40 g/l (60.00\%) recorded significantly higher mealybug mortality, followed by profenophos $50 \%$ EC @ $2 \mathrm{ml} / 1(51.11 \%)$ and dinotefuran 20 SG @ $0.25 \mathrm{~g} / \mathrm{l}(46.67 \%)$, which were all on par with each other. However, pymetrozine 50 WG @ $0.30 \mathrm{~g} / \mathrm{l}(24.44 \%)$ and buprofezin 25\% SC @ $2.00 \mathrm{ml} / \mathrm{l}(11.11 \%)$ showed significantly lower levels of mortality. On the contrary, azadirachtin@2.00 ml/1 and flonicamid @ $0.30 \mathrm{~g} / \mathrm{l}$ were statistically on par with each other by registering the lowest mealybug mortality of 2.22 per cent and 4.45 per cent, respectively. The insecticides in the decreasing order of their efficacy during 24 HAT were thiamethoxam $(0.40 \mathrm{~g} / \mathrm{l})>$ profenophos $(2.00$ $\mathrm{ml} / \mathrm{l})>$ dinotefuran $(0.25 \mathrm{~g} / \mathrm{l})>$ pymetrozine $(0.60 \mathrm{~g} / \mathrm{l})>$ buprofezin $(2.00 \mathrm{ml} / \mathrm{l})>$ flonicamid $(0.30 \mathrm{~g} / \mathrm{l})>$ azadirachtin $(2.00$ $\mathrm{ml} / \mathrm{l})($ Table 2; Fig 1).

The chitin synthesis inhibitor, buprofezin and the neem formulation, azadirachtin which are generally slow acting poisons, are generally expected to give good mortality may be 7th or 9th day after imposition of treatments. In the present study it was clear that, when the time of exposure of insecticides increased, the mortality of mealybugs also increased and vice versa (Table 2; Fig 1).

The survival trends of P. solenopsis at @ 24 HAT was found to be highest in case of untreated check (15.00), followed by azadirachtin (14.67) and flonicamid (14.33). Buprofezin (13.33) and pymetrozine (11.33) also recorded comparitively higher survivability of treated mealybugs. The lowest survivability of mealybugs was recorded in thiamethoxam (6.00), profenophos (7.33) and dinotefuran (8.00). From this, it could be inferred that, these chemicals are highly effective against mealybugs. The degree of survivability of mealybugs kept on reducing as the duration after treatment imposition increased (Table 3; Fig.2). The mean number of mealybugs that survived during 48, 72 and 96 HAT were decreased gradually and touched zero during 120 HAT, in case of thiamethoxam and profenophos.

However, at 24, 48, 72, 96 and 120 HAT, mortality due to thiamethoxam 25 WG @ $0.40 \mathrm{~g} / \mathrm{l}$, profenophos $50 \mathrm{EC} @ 2.00 \mathrm{ml} / \mathrm{l}$ and dinotefuran 20 SG @ 0.25 g/l were all statistically superior (Fig.1). The present study revealed that, thiamethoxam was the most effective insecticide for the control of mealybugs among all the treatments when applied at same or different concentrations and different durations of exposure. The second generation neonicotinoid, thiamethoxam 25 WG @ 0.40 g/l $(60.00 \%)$ followed by third generation neonicotinoid, dinotefuran 20 $\quad$ SG @ 0.25 g/l recorded significantly highest mealybug mortality from 24 to 120 hours after treatment imposition, indicating its ability to bring rapid mortality of the pest. One of the possible reasons for its efficacy can be its unique and broad spectrum of action. Both of them acts on many types of post synaptic nicotinic acetylcholine receptors present in the central nervous system of insects (Wismer, 2004). The present findings are in conformity with earlier works of Rashid et al., (2011) who reported thiamethoxam to be effective against $P$. solenopsis in cotton.

In an earlier laboratory study, on the efficacy of newer insecticides, flonicamid $50 \mathrm{WG}$ and dinotefuran $20 \mathrm{SG}$ were found to be effective on root mealybugs of rhapis palms. In this study, it was found that other insecticides namely spirotetramat and chlorantraniliprole were not effective on mealybugs (Arnold $e t$ al., 2013). These findings suggest that only select newer molecules are effective on mealybug species. 
Table.1 Screening of insecticides at three different dosages to instar nymphs of $P$. solenopsis

\begin{tabular}{|c|c|c|c|c|}
\hline Treatments & Treatment Details & \multicolumn{3}{|c|}{ Dosage (per litre of water) } \\
\cline { 3 - 5 } & & BR & R & AR \\
\hline T1 & Pymetrozine 50\% WG & $0.50 \mathrm{~g}$ & $0.60 \mathrm{~g}$ & $0.70 \mathrm{~g}$ \\
\hline T2 & Flonicamid 50\% WG & $0.20 \mathrm{~g}$ & $0.30 \mathrm{~g}$ & $0.40 \mathrm{~g}$ \\
\hline T3 & Dinotefuran 20\% SG & $0.15 \mathrm{~g}$ & $0.25 \mathrm{~g}$ & $0.35 \mathrm{~g}$ \\
\hline T4 & Thiamethoxam 25\% WG & $0.30 \mathrm{~g}$ & $0.40 \mathrm{~g}$ & $0.50 \mathrm{~g}$ \\
\hline T5 & Azadirachtin 1 \% EC & $1.50 \mathrm{ml}$ & $2.00 \mathrm{ml}$ & $2.50 \mathrm{ml}$ \\
\hline T6 & Buprofezin 25\% SC & $1.50 \mathrm{ml}$ & $2.00 \mathrm{ml}$ & $2.50 \mathrm{ml}$ \\
\hline T7 & Profenophos 50\% EC & $1.50 \mathrm{ml}$ & $2.00 \mathrm{ml}$ & $2.50 \mathrm{ml}$ \\
\hline T8 & Untreated check & -- & -- & - \\
\hline
\end{tabular}

$\mathrm{BR}=$ below recommended; $\mathrm{R}=$ recommended; $\mathrm{AR}=$ Above recommended concentrations

Table.2 Effect of new insecticide molecules at recommended dose on P. solenopsis under laboratory conditions

\begin{tabular}{|c|c|c|c|c|c|c|c|c|}
\hline \multirow[t]{2}{*}{ Treatments } & \multirow[t]{2}{*}{$\begin{array}{l}\text { Treatment } \\
\text { details }\end{array}$} & \multirow[t]{2}{*}{$\begin{array}{c}\text { Dosage } \\
\text { (g.a.i./ha) }\end{array}$} & \multirow{2}{*}{$\begin{array}{l}\text { Dosage } \\
\text { (per } \\
\text { litre of } \\
\text { water) }\end{array}$} & \multicolumn{5}{|c|}{$\begin{array}{l}\text { Mean cumulative mortality of mealybugs hours } \\
\text { after treatment (HAT) imposition (\%) }\end{array}$} \\
\hline & & & & 24 HAT & $\begin{array}{c}48 \\
\text { HAT }\end{array}$ & $\begin{array}{c}72 \\
\text { HAT }\end{array}$ & 96 НАТ & $\begin{array}{l}120 \\
\text { HAT }\end{array}$ \\
\hline T1 & $\begin{array}{l}\text { Pymetrozine } \\
50 \% \mathrm{WG}\end{array}$ & 150 & $0.60 \mathrm{~g}$ & $\begin{array}{c}24.44 \\
(29.46)^{b}\end{array}$ & $\begin{array}{c}35.55 \\
(36.59)^{\mathrm{c}}\end{array}$ & $\begin{array}{c}44.45 \\
(41.80)^{\mathrm{c}}\end{array}$ & $\begin{array}{c}62.22 \\
(52.19)^{\mathrm{b}}\end{array}$ & $\begin{array}{c}80.00 \\
(63.64)^{\mathrm{c}}\end{array}$ \\
\hline T2 & $\begin{array}{l}\text { Flonicamid } \\
50 \% \mathrm{WG}\end{array}$ & 75 & $0.30 \mathrm{~g}$ & $\begin{array}{c}4.45 \\
(20.23)^{\mathrm{cd}}\end{array}$ & $\begin{array}{c}8.89 \\
(17.12)^{\mathrm{e}}\end{array}$ & $\begin{array}{c}13.33 \\
(21.41)^{\mathrm{d}}\end{array}$ & $\begin{array}{c}22.22 \\
(28.07)^{\mathrm{c}}\end{array}$ & $\begin{array}{c}46.67 \\
(43.08)^{\mathrm{de}}\end{array}$ \\
\hline T3 & $\begin{array}{l}\text { Dinotefuran } \\
20 \% \text { SG }\end{array}$ & 25 & $0.25 \mathrm{~g}$ & $\begin{array}{c}46.67 \\
(43.08)^{\mathrm{a}}\end{array}$ & $\begin{array}{c}60.00 \\
(50.81)^{\mathrm{b}}\end{array}$ & $\begin{array}{c}73.33 \\
(59.03)^{\mathrm{b}}\end{array}$ & $\begin{array}{c}91.11 \\
(75.48)^{\mathrm{a}}\end{array}$ & $\begin{array}{c}95.55 \\
(79.78)^{\mathrm{b}}\end{array}$ \\
\hline T4 & $\begin{array}{l}\text { Thiamethoxam } \\
25 \% \text { WG }\end{array}$ & 50 & $0.40 \mathrm{~g}$ & $\begin{array}{c}60.00 \\
(50.81)^{\mathrm{a}}\end{array}$ & $\begin{array}{c}73.33 \\
(59.03)^{\mathrm{a}}\end{array}$ & $\begin{array}{c}93.33 \\
(80.65)^{\mathrm{a}}\end{array}$ & $\begin{array}{c}93.33 \\
(80.65)^{\mathrm{a}}\end{array}$ & $\begin{array}{l}100.00 \\
(89.26)^{\mathrm{a}}\end{array}$ \\
\hline T5 & $\begin{array}{c}\text { Azadirachtin } 1 \\
\% \text { EC (10000 } \\
\text { ppm })\end{array}$ & 1000 & $2.00 \mathrm{ml}$ & $\begin{array}{l}2.22 \\
(5.48)^{\mathrm{cd}}\end{array}$ & $\begin{array}{c}8.89 \\
(17.12)^{\mathrm{e}}\end{array}$ & $\begin{array}{c}15.55 \\
(23.13)^{d}\end{array}$ & $\begin{array}{c}44.44 \\
(41.75)^{\mathrm{bc}}\end{array}$ & $\begin{array}{c}57.78 \\
(49.48)^{\mathrm{d}}\end{array}$ \\
\hline T6 & $\begin{array}{c}\text { Buprofezin } \\
25 \% \mathrm{SC}\end{array}$ & 250 & $2.00 \mathrm{ml}$ & $\begin{array}{c}11.11 \\
(16.24)^{\mathrm{c}}\end{array}$ & $\begin{array}{c}17.78 \\
(24.85)^{\mathrm{d}}\end{array}$ & $\begin{array}{c}20.00 \\
(26.36)^{d}\end{array}$ & $\begin{array}{c}33.33 \\
(35.19)^{\mathrm{c}}\end{array}$ & $\begin{array}{c}44.44 \\
(41.79)^{\mathrm{c}}\end{array}$ \\
\hline T7 & $\begin{array}{l}\text { Profenophos } \\
50 \% \text { EC }\end{array}$ & 500 & $2.00 \mathrm{ml}$ & $\begin{array}{c}51.11 \\
(45.64)^{\mathrm{a}}\end{array}$ & $\begin{array}{c}73.33 \\
(59.03)^{\mathrm{a}}\end{array}$ & $\begin{array}{c}95.56 \\
(82.37)^{\mathrm{a}}\end{array}$ & $\begin{array}{c}97.78 \\
(84.52)^{\mathrm{a}}\end{array}$ & $\begin{array}{c}100.00 \\
(89.26)^{\mathrm{a}}\end{array}$ \\
\hline T8 & $\begin{array}{l}\text { Untreated } \\
\text { check }\end{array}$ & -- & -- & $\begin{array}{c}0.00 \\
(0.74)^{\mathrm{d}}\end{array}$ & $\begin{array}{c}0.00 \\
(0.74)^{\mathrm{f}}\end{array}$ & $\begin{array}{c}2.22 \\
(5.48)^{\mathrm{e}}\end{array}$ & $\begin{array}{c}4.45 \\
(10.23)^{\mathrm{d}}\end{array}$ & $\begin{array}{c}8.89 \\
(17.12)^{f}\end{array}$ \\
\hline \multicolumn{4}{|c|}{ F test } & $*$ & $*$ & $*$ & $*$ & $*$ \\
\hline \multicolumn{4}{|c|}{$\operatorname{SEm}( \pm)$} & $(3.99)$ & (1.99) & $(4.51)$ & $(4.98)$ & $(2.45)$ \\
\hline \multicolumn{4}{|c|}{$\mathrm{CD}(p=0.05)$} & (11.96) & (5.96) & (13.53) & (14.94) & (7.35) \\
\hline \multicolumn{4}{|c|}{$\mathrm{CV}(\%)$} & $(27.41)$ & (10.39) & $(18.37)$ & $(16.92)$ & $(7.17)$ \\
\hline
\end{tabular}

Figures in parentheses are means of angular transformed values. In each column, means followed by same alphabets are statistically on par by DMRT $(p=0.05)$ 
Table.3 Mean survival of mealybugs after treatment imposition (Survival trend of mealybugs)

\begin{tabular}{|c|c|c|c|c|c|c|c|}
\hline \multirow[t]{2}{*}{ Treatment details } & \multirow[t]{2}{*}{$\begin{array}{c}\text { Dosage } \\
\text { (g.a.i./ha) }\end{array}$} & \multirow{2}{*}{$\begin{array}{l}\text { Dosage } \\
\text { (per } \\
\text { litre of } \\
\text { water) }\end{array}$} & \multicolumn{5}{|c|}{$\begin{array}{l}\text { Mean number of mealybugs survived during } \\
\text { different hours after treatment (HAT) } \\
\text { imposition }\end{array}$} \\
\hline & & & $\begin{array}{c}24 \\
\text { HAT }\end{array}$ & $\begin{array}{c}48 \\
\text { HAT }\end{array}$ & 72 HAT & $\begin{array}{c}96 \\
\text { HAT }\end{array}$ & $\begin{array}{c}120 \\
\text { HAT }\end{array}$ \\
\hline T1 - Pymetrozine 50\% WG & 150 & $0.60 \mathrm{~g}$ & 11.33 & 9.67 & 8.33 & 5.67 & 3.00 \\
\hline T2 - Flonicamid $50 \%$ WG & 75 & $0.30 \mathrm{~g}$ & 14.33 & 13.67 & 13.00 & 11.67 & 8.00 \\
\hline T3 - Dinotefuran 20\% SG & 25 & $0.25 \mathrm{~g}$ & 8.00 & 6.00 & 4.00 & 1.33 & 0.67 \\
\hline T4 - Thiamethoxam 25\% WG & 50 & $0.40 \mathrm{~g}$ & 6.00 & 4.00 & 1.00 & 1.00 & 0.00 \\
\hline $\begin{array}{l}\text { T5 - Azadirachtin } 1 \% \text { EC } \\
\text { (10000 ppm) }\end{array}$ & 1000 & $2.00 \mathrm{ml}$ & 14.67 & 13.67 & 12.67 & 8.33 & 6.33 \\
\hline T6 - Buprofezin $25 \% \mathrm{SC}$ & 250 & $2.00 \mathrm{ml}$ & 13.33 & 12.33 & 12.00 & 10.00 & 8.33 \\
\hline T7 - Profenophos 50\% EC & 500 & $2.00 \mathrm{ml}$ & 7.33 & 4.00 & 0.67 & 0.33 & 0.00 \\
\hline T8 - Untreated check & -- & -- & 15.00 & 15.00 & 14.67 & 14.33 & 13.67 \\
\hline
\end{tabular}

NB: Initial number of instar nymphs used $=15$

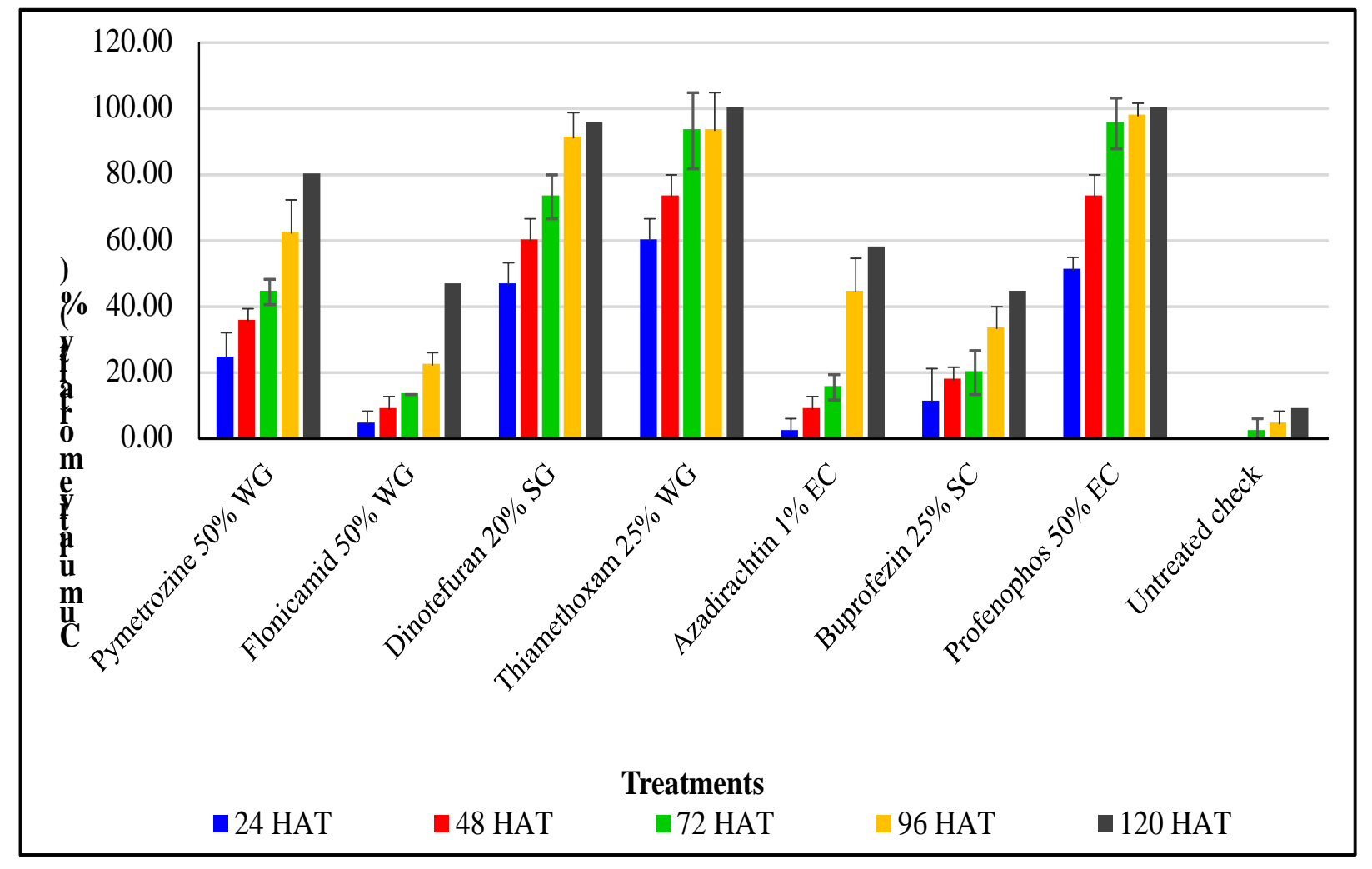

Fig.1 Effect of new insecticide molecules on P. solenopsis under laboratory condition 


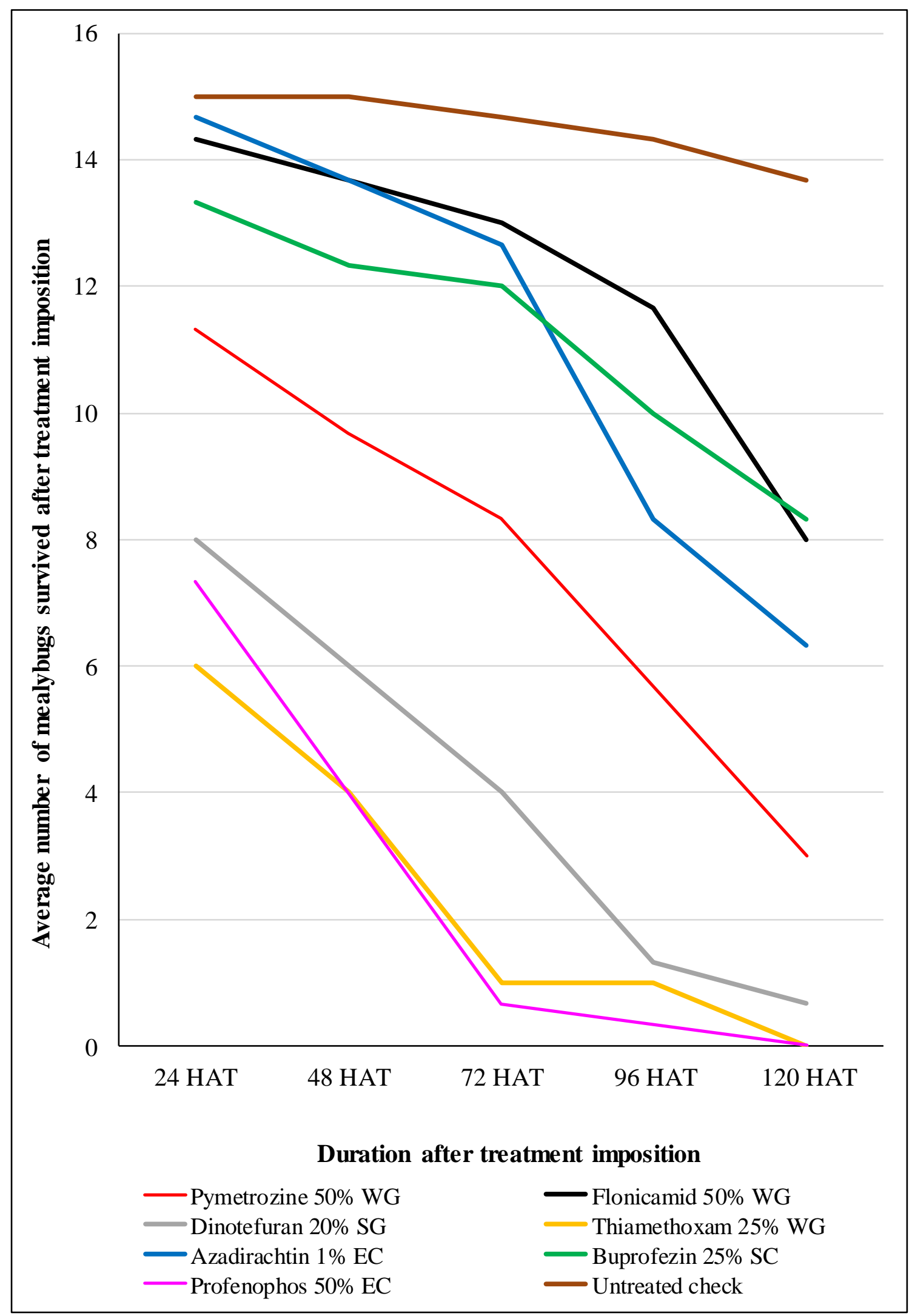

Fig.2 Mean survival of mealybugs after treatment imposition 
Qiao-li et al., (2014) tested the relative toxicity of a few select insecticides against 3rd instar nymphs of solenopsis mealybug, with leaf dipping method and found that at 24 hours after treatment, relative toxicity of some insecticides from high to low was lambdacyhalothrin, profenophos, chlorpyriphos, avermectins, phoxim, carbosulfan, spinosad, chlorfenapyr, beta-cypermethrin, methomyl, emamectin benzoate, triazophos, petroleum oil, and rotenone in that decreasing order of effectiveness.

Seni and Sahoo (2015) tested the bio-efficacy of some insecticides against papaya mealybug, Paracoccus marginatus Williams and Granara de Willink and revealed that after 24 hours, chlorpyriphos 20 EC (LC50 $21 \mu 1 / 1)$ and thiamethoxam $25 \mathrm{WG}$ (LD50 $44 \mathrm{mg} / \mathrm{l}$ ) were the most toxic and buprofezin $25 \mathrm{SC}$ (LC50 $1000 \mu \mathrm{l} / \mathrm{l}$ ) was the least toxic among the insecticides subjected to bioassay (Potato dip method). In case of field trials, thiamethoxam $25 \mathrm{WG}$, spirotetramat $240 \mathrm{EC}$, imidacloprid 17.8 SL, dimethoate $30 \mathrm{EC}$, lamdacyhalothrin $5 \mathrm{EC}$ and buprofezin $25 \mathrm{SC}$ were found effective for the management of the papaya mealybug.

Similar studies were conducted by Chandrashekar et al., (2011) who reported different trend of mortality for buprofezin. The results of the present study differ from the observations of Chandrashekar et al., (2011) who evaluated buprofezin against nymphs of $P$. solenopsis infesting sunflower under glass house conditions. Profenophos and buprofezin recorded the highest mortality of 95.74 and 92.35 per cent, respectively, whereas in the present study, profenophos recorded significantly highest mortality, but not buprofezin.

The effect of new insecticide molecules at different concentrations and durations of exposure against solenopsis mealybugs on treated potato sprouts in the laboratory revealed that none of the insecticides treated recorded cent per cent mortality when used at below recommended, recommended and the above recommended concentrations. However, insecticides viz., thiamehoxam 25 WG, dinotefuran $20 \mathrm{SG}$, and profenophos 50 EC recorded highest mortality when used at recommended concentrations and 50 per cent below the recommended concentrations. Effectiveness of all these insecticides were evaluated under laboratory conditions.

A preliminary trial with three different dosages (below recommended, recommended and above recommended) were tried for each of the insecticidal treatments. The mortality of mealybugs was found to be more in the treatment with recommended dosage when compared to below recommended dose. After a span of 96 hours from inception of treatment, 90 per cent mortality was recorded in case of below recommended dosage whereas, in recommended and above recommended dose, it was found to be the same (i.e., 98.33\%). At 120 hours after initiation of treatment imposition, cent per cent mortality was found in case of recommended and above recommended dose. Since the requisite mortality was achieved in recommended dosage itself, the same was used for further experimentation.

The selected insecticides in the laboratory assay at recommended concentrations were sprayed on potato sprouts infested with mealybug among which the treatment, thiamethoxam 25 WG @ $0.40 \mathrm{~g} / 1$ recorded the highest mealybug mortality at 24 HAT (60.00 $\%), 48$ HAT (73.33 \%), 72 HAT (93.33\%), 96 HAT $(93.33 \%)$ and 120 HAT $(100.00 \%)$ owing to its broad spectrum of action and good translocation ability into plant tissues. The third generation neonicotinoid, dinotefuran 20 SG @0.25 g/l also recorded significant effects in reducing mealybug 
population at $24 \mathrm{HAT}(46.67 \%), 48 \mathrm{HAT}$ (60.00\%), 72 HAT (73.33\%), 96 HAT (91.11\% and 120 HAT $(95.55 \%)$ owing to its good knock down effect and unique mode of action (Strong systemic and translaminar action).

\section{References}

Arnold, H. H., Susan, K. C. and Kris, L. A., 2013, foliar and drench applications of insecticides against root mealybugs in containerized Rhapis palms. Ann. Pl. Protec. Sci., 38(1): 55-64.

Chandrashekar, Jagadish, K. S., Kumar, N. G., Shadakshari, Y. G., Nagaraju. and Shivayya, V., 2011, Bio-ecology and chemical control of the mealybug, Phenacoccus solenopsis Tinsley (Homoptera: Pseudococcidae) infesting sunflower (Helianthus annuus L.). M. Sc. Thesis (Unpub.), Univ. Agric. Sci., Bengaluru.

Ghelani, M. K., Kabaria, B. B. and Chhodavadia, S. K., 2014, Field efficacy of various insecticides against major sucking pests of $\mathrm{Bt}$ cotton.J. Biopest., 7(5):27-37.

Muthukrishnan, N., Manoharan, T., Thirumalai Thevan, P. S. and Anbu, S., 2005. Evaluation of buprofezin for the management of grape mealy bug, Maconellicoccus hirsutus (Green). J. Ent. Res., 29(4): 339-344.

Qiao-Li, L., Guang-Wen, L. and Yong-Yue, L., 2014, Toxicity of 14 insecticides to cotton mealybug Phenacoccus solenopsis Tinsely with leaf dipping method. Guangdong Agric. Sci., 201406.http://en.cnki.com.cn/Articleen/CJFDTOTALGDNY201406027. htm dated 06. 12. 2017.

Rashid, M. M., Khattak, M. K., Abdullah, K. and Hussain, S., 2011, Toxic and residual activities of selected insecticides and neem oil against cotton mealybug, Phenacoccus solenopsis Tinsley (Sternorrhyncha: Pseudococcidae) under laboratory and field condition. Pak. Entomol., 33(2): 151-155.

Seni, A. and Sahoo, A. K., 2015, Efficacy of certain insecticides on papaya mealybug, Paracoccus marginatus Williams \& Granara de Willink (Hemiptera: Pseudococcidae). J. Ent. Zoo. Studies., 3(4): 14-17.

Wismer, T., 2004, Novel insecticides in clinical veterinary toxicology, $K . H$. Plum Lee, Ed., Mosby, St Louis, Miss, USA, pp. 184-185.

\section{How to cite this article:}

Nidheesh. T. D., A. H. Jayappa, A. N. Shylesha, N. Nagaraju and Jayadeva. H. M. 2020. Screening of New Insecticide Molecules Against Cotton Mealybug, Phenacoccus Solenopsis Tinsley (Homoptera: Pseudococcidae). Int.J.Curr.Microbiol.App.Sci. 9(03): 2542-2550. doi: https://doi.org/10.20546/ijcmas.2020.903.291 